\author{
A.R. Yeshkeyev \\ Ye.A. Buketov Karaganda State University, Kazakhstan \\ (E-mail: modth1705@mail.ru)
}

\title{
The properties of central-orbital types of EPSCJ theories
}

\begin{abstract}
This article, in its content, refers to the study of the theoretical-model properties of the Jonsson theories. A new approach to this study is proposed. As a new notion, the idea of a central-orbital type is used. When studying Jonsson theories are taken into account the following facts:Syntactic, concerning the Jonsson theories and the Jonsson subsets of the semantic model of the Jonsson theory under consideration.In addition, a special role in the syntactic sense is played by the enrichment of the signature associated with the given Jonsson sets. The semantic aspect of the issues under consideration is primarily concerned with the notion of convexity, strong convexity, and existential primeness.Although these definitions are related to theory, in fact we are dealing with different types of models that are existentially closed.
\end{abstract}

Keywords: Jonsson theory, Jonsson set, fragment of Jonsson sets, Existentially Prime Strongy Convex Jonsson theories, central-orbital types.

This work is associated with the concepts of convexity theory in the class existentially-prime Jonsson theories. We denote such theories as Existentially Prime Strongy Convex Jonsson (EPSCJ). Also we have concentrating our attention to not arbitrary subsets but use have deal with Jonsson subsets of some semantic model for fixing Jonsson theory [1-3].

Let $L$ be a countable first-order language.

Definition 1. The inductive theory $T$ called existential-prime, if

1. It has an algebraic prime model and the class of all algebraically prime models denoted by $A P$.

2. The class $E_{T}$ existentially closed models of theory $T$ has non-empty intersection with an $A P$ class, i.e., $T_{A P} \cap E_{T} \neq \emptyset$.

Definition 2 . The theory $T$ is called convex if for any model $\mathfrak{U}$ and any family $\left\{\mathfrak{B}_{i} \mid i \in I\right\}$ of its substructures, which are models of the theory $T$, the intersection $\bigcap_{i \in I} \mathfrak{B}_{i}$ is a model theory $T$. It is assumed that this intersection is not empty. If this intersection is never empty, then the theory is called the strongly convex.

The following notions belong to A. Robinson [4].

Definition 3. The set $X$ is said to be Jonsson in theory $T$ if it satisfies the following properties:

1) $X$ is a $\Sigma$ - definable subset of $C$;

2) $d c l(X)$ is the universe of some existentially closed submodel $C$.

It is well known [1] that if Jonsson Theories $T$ is perfect, then the class of its existentially closed models $E_{T}$ is elementary and coincides with the $M o d T^{*}$, where $T^{*}-$ its center. Otherwise, i.e. if the theory $T$ is not perfect, instead of $M o d T$ we are working with the class $E_{T}$, i.e., it is assumed that all the allegations relate only existentially closed models. Also, we assume in the case of an imperfect, that besides the existential closure of all these models is algebraically prime.

We say that all $\forall \exists$ - corollary of the arbitrary theory form a Jonsson fragment of this theory, if the deductive closure of these $\forall \exists$ - corollary is Jonsson Theories. Obtained in this case Jonsson theories will be called Jonsson fragment (further fragment). Accordingly, it is determined by the fragment of Jonsson set. In both cases, we can carry out research Jonsson fragments on the connection with an initial theory that the new formulation of the problem research is Jonsson's theory.

Let $X$ Jonsson set in the theory $T$ and $M$ is existentially closed submodel of semantic model $C$, considered Jonsson theory $T$ where $d c l(X)=M$. Then let $\operatorname{Th} h_{\forall \exists}(M)=\operatorname{Fr}(X), \operatorname{Fr}(X)$ is Jonsson fragment of Jonsson sets $X$.

\section{Pure triples of complete theories}

The following definitions belong to T.G. Mustafin [5; 49].

Definition 4. If $A$ is non-empty set, $G$ is some group of bijections (permutations) $A$ relative to the superposition, then the pair $(A, G)$ is called a pure pair (p.p.). 
Definition 5. The triple $(A, G, N)$ is called a pure triple (p.t.), if:

1) $(A, G)$ is p.p.;

2) $N$ - some class of subsets $A$ such that $g(M) \in N$ for all $M \in N, g \in G$, where $g(M) \rightleftharpoons\{g(a): a \in M\}$. If $(A, G, N),\left(A^{\prime}, G^{\prime}, N^{\prime}\right)$ is p.t., $\varphi: A \rightarrow A^{\prime}$ - bijection, then $\varphi$ Is called an exact similarity (isomorphism) if:

a) $G^{\prime}=\left\{\varphi g \varphi^{\prime}: g \in G\right\}$

b) $N^{\prime}=\{\varphi(M): M \in N\}$.

If $(A, G, N)$ - p.t., $\sim-G$ - invariant equivalence relation on $A$, then $\sim$ is called a congruence on $(A, G, N)$, if $\forall a \in A \forall M \in N(a \in M \Rightarrow \tilde{a} \in M)$.

Proposition 1. If $\sim$ is a congruence on p.t. $(A, G, N)$, then $(A / \sim, G / \sim, N / \sim)$ is p.t., where $N / \sim=\{M / \sim: M \in N\}$.

$\triangleright$ easy to verify.

If $(A, G, N),\left(A^{\prime}, G^{\prime}, N^{\prime}\right)$ - p.t., $\varphi: A \rightarrow A^{\prime}$ is surjection, then $\varphi$ is called compression in $\varphi^{-1}$ is called bloating, if:

1) the relation $\tilde{\varphi}$ is a congruence,

where $a \tilde{\varphi} b \rightleftharpoons \varphi(a)=\varphi(b) . a, b \in A$;

2) the map $\psi: A^{\prime} \rightarrow A / \sim$ is an exact similarity, where $\psi\left(a^{\prime}\right)=\left\{a \in A: \varphi(a)=a^{\prime}\right\}, a^{\prime} \in A^{\prime}$.

Let $T$ is Jonsson theory and $T^{*}=T h(\mathcal{L})$ is center, i.e. where $\mathcal{L}$ is a semantic model of the theory $T$. $G=\operatorname{Aut}(\mathcal{L}), N=E_{T}$, where $E_{T}$ is the class of all existentially closed models theory $T$. Then p.t. $(\mathcal{L}, G, N)$ is called the semantic triple (s.t.) of Jonsson theory $T$. Jonsson theories $T_{1}, T_{2}$ are called semantically exactly similar if their semantic triples are exactly similar.

Remark. The concept of exact similarity of theories does not depend on the choice of the semantic model.

Let $\varepsilon$ is such relation on $\mathcal{L}$, that:

- if $a \in \operatorname{acl}(\emptyset)$, then $b \varepsilon a \Leftrightarrow b=a$;

- if $a, b \notin a c l(\emptyset)$, then $b \varepsilon a \Leftrightarrow \operatorname{acl}(b)=\operatorname{acl}(a)$.

We have the following results by analogy with the results of [5].

Lemma 1. In p.t. $(\mathcal{L}, G, N)$ the relation $\varepsilon$ is congruence.

If $\left(\mathcal{L}_{i}, G_{i}, N_{i}\right)$ are s.t. of theory $T_{i}, i=1,2$, then $T_{1}$ and $T_{2}$ are called $\varepsilon$ are similar if $\left(\mathcal{L}_{1} / \varepsilon, G_{1} / \varepsilon, N_{1} / \varepsilon\right)$ and $\left(\mathcal{L}_{2} / \varepsilon, G_{2} / \varepsilon, N_{2} / \varepsilon\right)$ exactly similar. It is easy to see that the relation " $\varepsilon$ is similar" is an equivalence relation in the class of Jonsson theories.

Proposition 2. Let $(A, G, N)$ is p.t., $\left(\mathcal{L}_{i}, C_{i}, N_{i}\right)$ s.t. existentially complete perfect Jonsson theories $T_{i}, i=1,2$, $\psi_{i}: \mathcal{L}_{i} \rightarrow A_{i}$ are compression, $i=1,2$. If $X_{i} \subset \mathcal{L}_{i}, i=1,2$, then let $X_{1}=X_{2}$ means that $\psi_{1}\left(X_{1}\right)=\psi_{2}\left(X_{2}\right)$. Then:

1) $I\left(\alpha, T_{1}^{*}\right)=I\left(\alpha, T_{2}^{*}\right)$ for all $\alpha \Leftrightarrow I\left(\alpha, E_{T_{1}}\right)=I\left(\alpha, E_{T_{2}}\right)$, where $E_{T_{i}}$ is number of existentially closed models of theory $T_{i}$;

2) for all $\lambda$ is true that $T_{1}-\lambda$ is stable $\Leftrightarrow T_{2}-\lambda$ is stable;

3) if $\bar{a}_{1}=\bar{a}_{2}, M_{1} \leftrightarrow M_{2}, M_{i} \in N_{i}, i=1,2$, then

a) $\bar{a}_{1}=\bar{a}_{2}, \bar{a}_{1} \in M_{1} \Leftrightarrow \bar{a}_{2} \in M_{2}$;

b) $L\left(t p\left(\bar{a}_{1}, M_{1}\right)\right)=L\left(t p\left(\bar{a}_{2}\right), M_{2}\right)$;

c) $t p\left(\bar{a}_{1}, M_{1}\right)$ is regular $\Leftrightarrow t p\left(\bar{a}_{2}, M_{2}\right)$ is regular;

d) $t p\left(\bar{a}_{1}, M_{1} \cup X_{1}\right) \lambda M_{1} \Leftrightarrow t p\left(\bar{a}_{2}, M_{2} \cup X_{2}\right) \lambda M_{2}$;

$\triangleright$ routine, so it is omitted.

The Jonsson theories $T_{1}$ and $T_{2}$ are called $\tau$ is similar, if there exist countable existentially closed models $M_{1} \models T_{1}, M_{2}=T_{2}$ such that $T h_{\forall \exists}\left(M_{1}, m\right)_{m \in M_{1}}$ and $T h_{\forall \exists}\left(M_{2}, m\right)_{m \in M_{2}} \varepsilon$ is similar.

Using Proposition 2, we can prove the following

Proposition 3.

1) If $T_{1}$ and $T_{2}$ are existentially complete perfect Jonsson theories $\varepsilon$ is similar, $M_{i} \in N_{i}, M_{1}=M_{2}$ (In the sense of Proposition 2), then $T h_{\forall \exists}\left(M_{1}, m\right)_{m \in M_{1}}$ and $T h_{\forall \exists}\left(M_{2}, m\right)_{m \in M_{2}} \varepsilon$ are similar;

2 ) relation $\ll \tau$ is similar» is an equivalence relation.

We give the necessary definitions related to Jonsson theories in the enriched signature.

Let $T$ is an arbitrary Jonsson theory in the language of the first order signature $\sigma$. Let $C$ is a semantic model of theory $T$. Let $A \subseteq C$ is a Jonsson set of theory $T$. Let $\sigma_{\Gamma}(A)=\sigma \cup\left\{c_{a} \mid a \in A\right\} \cup \Gamma, \Gamma=\{P\} \cup\{c\}$.

Let $T_{A}^{C}=T \cup T h_{\forall \exists}(C, a)_{a \in A} \cup\left\{P\left(c_{a}\right) \mid a \in A\right\} \cup\{P(c)\} \cup\left\{{ }^{\prime \prime} P \subseteq^{\prime \prime}\right\}$ where $\left\{{ }^{\prime \prime} P \subseteq^{\prime \prime}\right\}$ is an infinite set of sentences expressing the fact that the interpretation of symbol $P$ is existentially closed submodel in the language of the 
signatures $\sigma_{\Gamma}(A)$ and this model is a definable closure of the set $A$. It is understood that the consideration the set of sentences is Jonsson theory and this theory generally is not complete.

Let $T^{*}$ is the center of the Jonsson theory $T_{A}^{C}$ and $T^{*}=T h\left(C^{\prime}\right)$ where $C^{\prime}$ is a semantic model of the theory $T_{A}^{C}$. By restriction theory $T_{A}^{C}$ to signatures $\sigma_{\Gamma}(A) \backslash\{c\}$ the theory $T_{A}^{C}$ becomes a complete type. This type we call a central type of the theory $T$ relatively the Jonsson set $A$ and denoted by $P_{A}^{C}$.

Let $T$ is an arbitrary EPSCJ theory in first order signature $\sigma$. Let $C$ is a semantic model of $T$. $A \subseteq C$. The requirement of existential closeness for a submodel is essential in that sense, that it should not be finite. The theory $T_{A}^{C}$ is not necessary complete. Through $S_{\Gamma}^{A}$ denote a set of all $\exists$ - completions of theory $T_{A}^{C}$. Let $\lambda$ is an arbitrary cardinal.

Accordingly, the main idea of this clause of the article is to redefine all concepts, introduced by T.G. Mustafin for orbital types in [5], also in the language of central orbital types and then get the corresponding results in the language pure pair corresponding of Jonsson theory.

We give the Jonsson definition of some important model-theoretic concepts in the language pure pair $(A, G)$, where $A$ is some subsets of the semantic model and $G$ is automorphism group of semantic model.

Let $(A, G)$ is an arbitrary pure pair $X \subseteq A$ :

1. $G_{x} \leftrightarrows\{g \in G: \forall x \in X(g(x)=x)\}$. It is obvious that $G_{x} \subseteq G$.

2. If $Y \subseteq A$, то $G_{x}(Y) \leftrightarrows\left\{g(Y): g \in G_{x}\right\}$. If $Y=\{a\}$, then we will use the record $G_{x}(a)$. $G_{x}(Y)$ is called $G_{x}$ orbit $Y$.

3. If $0<n<\omega$, then $0^{n}(X) \leftrightarrows\left\{G_{x}\left(\bar{a} ; \bar{a} \in A^{n}\right)\right\}$

4. $\operatorname{acl}(X) \leftrightarrows\left\{a \in A:\left|G_{x}(a)\right|<\omega\right\}$.

5. The sequence $E=\left\langle\overline{e_{i}}: i<A\right\rangle$ finite sequences (tuples) the same length is called indistinguishable over $X$, if:

a) $\overline{e_{i}} \neq \overline{e_{j}}$ for all $i<j<a$;

b) for any sequence $\left\langle i_{k}: k<m<\omega\right\rangle$ indices such that $i_{k}<i_{s} \Leftrightarrow k<s$ for all $k, s \leq m$, exist $g \in G_{x}$, such that $g\left(\left\langle e_{k}: k \leq m\right\rangle\right),\left\langle e_{i_{k}}: k \leq m\right\rangle$.

6. If $(I ;<)$ is linearly ordered set of indices, then the sequence $E=\left\langle\overline{e_{i}}: i \in I\right\rangle$ is called indistinguishable over, if for all $I_{0} \subseteq I$, such that $\operatorname{ord}\left\langle I_{0}=\omega\right\rangle, E=\left\langle e_{i}: i \in I\right\rangle$ is indistinguishable over $X$ sequence.

7. The set $E=\left\langle\overline{e_{i}}: i \in I\right\rangle$ sequences of the same length are said to be indistinguishable over $X$, if:

a) $\overline{e_{i}} \neq \overline{e_{j}}$ при $i \neq j$;

b) for all $F, D \subseteq E$, such that $|F|=|D|<\omega$ and any bijection $\psi: F \rightarrow D$ exist $g \in G$ such that $\psi \in g$.

8. If $X \subseteq Y, p \in O^{n}(Y)$, then $p$ is called:

a) splitting over $X$, if there are such $\bar{a}, \bar{b} \in Y$, that $G_{x}(\bar{a})=G_{x}(\bar{b})$, but for all $\bar{c} \in p G_{x \cup \bar{c}}(\bar{a}) \cap G_{x \cup \bar{b}}=\bar{c} \in p(\varphi)$;

b) strictly splitting over $X$, if there exists such an indistinguishable $X$ infinite sequence $E\left\langle\overline{a_{i}}: i\langle\omega\rangle\right.$ in $A$, that $\overline{a_{0}}, \overline{a_{1}} \in Y$, and for all $\bar{c} \in p$ occurs $G_{x \cup \bar{c}}(\bar{a}) \cap G_{x \cup \bar{c}}(\bar{b})=\bar{c} \in p(\varphi)$;

c) branching over $X(p \curlywedge X)$, if there is such a $Z \supseteq Y$, that $|Z \backslash Y|<\omega$, and for all $q \in O^{n}(Z)$ from the fact that $q \leq p$, follows that $q$ is strictly splitting over $X$.

9. Subset $X \subseteq A$ is called $\lambda$ is saturated if $\forall Y \subseteq X, \forall p \in O^{1}(Y)<\lambda \Rightarrow X \cap p \neq(\varphi)$.

10. Pure pair $(A, G)$ is called $\lambda$ is stable if $\forall X \subseteq A\left(|X| \leq \lambda \Rightarrow\left|O^{1}(X)\right| \leq \lambda\right)$.

11. Let $O(A) \leftrightarrows \bigcup\left\{\bigcup_{n<\omega} O^{n}(X): X \subseteq A,|X|<|A|\right\}$.

By induction, we define the rank function $L: O(A) \rightarrow \operatorname{Ord} \cup\{\infty\}$ :

a) $L(p) \geq 0$ for all $p \in O(A)$;

b) if $\alpha$ is the limit ordinal, then $L(p) \geq \alpha$ if and only if $L(p) \geq \beta$ for all $\beta<\alpha$;

c) if $\alpha=\beta+1, p \in O^{n}(X)$, then $L(p) \geq \alpha$ if and only if $L(p) \geq \beta$ and there are $Y \subseteq A, q \in O^{n}(Y)$, that $X \subseteq Y, q \subseteq p, L(q) \geq \beta$ и $q \curlywedge X ;$

d) $L(p)=\alpha \Leftrightarrow L(p) \geq \alpha \vee L(p) \nsupseteq \alpha+1$;

e) $L(p)=\infty \Leftrightarrow L(p) \geq \alpha$ for all ordinals $\alpha$.

12. If $\bar{a}, \bar{b} \in A^{n}$, then $\vec{v}(\bar{a}, X)=\vec{x}(\bar{b}, X)$ means that there are such $Y, p \in O^{n}(Y)$, что $X \subseteq Y, Y \omega X \subseteq Y$ is saturated $p \curlywedge X, \bar{a}, \bar{b} \in p$.

13. $V^{n}(X) \leftrightarrows\left\{\vec{v}(\bar{a}, X) ; \bar{a} \in A^{n}\right\}, V(X)=\bigcup_{n<\omega} V^{n}(X)$

If $p \in O^{n}(X)$, then $V_{p}\left\{\vec{v}(\bar{a}, X):^{a} \in p\right\}$.

14. If $X \subseteq Y, \vec{\omega} \in V^{n}(X), \vec{u} \in V^{n}(Y)$, then

$$
\vec{\omega}<\vec{u} \leftrightarrows \forall \bar{a}, \bar{b} \in A^{n}\left(\vec{\omega}=\vec{v}(a, X) \vee \vec{u}=\vec{v}(\bar{b}, Y) \Rightarrow \vec{v}(\bar{a}, X)=\vec{v}(\bar{b}, X) \wedge G_{\gamma}(\bar{b}) \curlywedge X\right) .
$$

15. The sequence $\left\langle\overline{a_{i}}: i\langle a\rangle\right.$ is called the Morley sequence over $X$, generated $\bar{u}$ from $V^{n}(X)$, if $\vec{u}<\vec{v}\left(\overline{a_{j}}, X \cup \bigcup_{j<i} \overline{a_{j}}\right)$ for all $i<a$. 
16. Let's call $\bar{u}, \bar{\omega} \in V(X)$ almost orthogonal (we denote by $\left.\vec{u} \perp^{\alpha} \bar{\omega}\right)$, if $\forall \bar{a}, \bar{b} \in A(\vec{u}=\vec{v}(\bar{a}, X) \wedge \vec{\omega}=$ $=\vec{v}(\bar{b}, X)) \Rightarrow G_{X \cup \bar{b}}(\bar{a}) \curlywedge X$.

17. Let's call $p, q \in O(X)$ almost orthogonal (we denote by $p \perp^{\alpha} q$ ), если $\vec{u} \in V_{p}, \vec{\omega} \in V_{q}$.

18. Let's call $\bar{u} \in V(X), \bar{\omega} \in V(Y)$ almost orthogonal (we denote by $\vec{u} \perp^{\alpha} \bar{\omega}$ ), if $\forall Z \forall \vec{u}, \overline{\omega_{1}} \in V(Z)$ $\left(X \cup Y \subseteq Z \wedge \vec{u}<\overrightarrow{u_{1}} \wedge \vec{\omega}<\overrightarrow{\omega_{1}} \Rightarrow \overrightarrow{u_{1}} \perp^{\alpha} \overrightarrow{\omega_{1}}\right)$.

19. Let's call $p \in O(X), q \in O(Y)$ almost orthogonal (we denote by $p \perp q$ ), if $q \subseteq V_{p} \forall \vec{\omega} \in V_{q}(\vec{u} \perp \vec{\omega}$ ).

20. Let's call $p \in O(X)$ regular if

$$
\forall Y \forall q \in O(Y)(X \in Y \wedge q \subseteq p \wedge q \wedge X \Rightarrow p \perp q) .
$$

All the concepts introduced in this way related to central-orbital types of the Jonsson theory naturally give Jonsson analogues of theorems for complete theories. First of all, we are interested in describing models of central types of Jonsson algebras with respect to stability topics. Let $L$ is an arbitrary language. Let $T$ are Jonsson's perfect theory, complete for existential sentences in the language $L$, and its semantic model is $C$. We say that the set $X \Sigma$ is definable if it is definable by some existential formula.

The set $X$ is called algebraically Jonsson in theory $T$, if it satisfies the following properties:

$-X$ is $\Sigma$ is definable subset $C$;

$-\operatorname{acl}(X)$ is the universe of some existentially closed submodel $C$.

With the help of the introduced definitions of Jonsson sets, we can transfer many properties for the Jonsson theories to Jonsson and algebraically Jonsson subsets of the semantic model.

We say that two Jonsson (algebraically) sets (equivalent, cosmetic, categorical), if there are, respectively, (Jonsson equivalent, kosemantic, categorical, syntactically similar, semantically similar, etc.) the models obtained by the corresponding closure of these sets. Consider, for example, kosemantic. Two Jonsson sets are cosemantic, if their respective closures are cosmetic, etc. The most invariant concept is the syntactic similarity of theories, since it preserves all the properties of the theories under consideration. For the case of Jonsson sets, we define the syntactic similarity as follows: two (algebraic) Jonnson sets are syntactically similar to each other if the elementary theories of their corresponding closures are syntactically similar. If $\forall \exists$ is the consequences of these elementary theories will be given by the Jonsson theories, then in this case we can consider their Jonsson syntactic similarity, i.e. to the invariance of the semantic model, our definition is correct. In conclusion, we will make a far-reaching proposal.

In this article the new definitions, we set the task of considering and attempting to describe strongly minimal Jonsson sets.This, in turn, entails a whole series of new problem statements, for example, refinement of the Lachlan-Baldwin theorem in the framework of this novelty. And finaly we claim that for central-orbital types will be true all results from [6] and also the following result:

Let us consider the stability for fragments of Jonsson sets.

Let $X$ Jonsson set and $M$ is existentially closed model, where $d c l(X)=M$.

Consider the fragment of Jonsson set $X$ as the theory $T h_{\forall \exists}(M)=T_{M}$.

Lemma 2. $T_{M}$ will Jonsson theory in the enrichment as above signature.

Theorem 1. Let $T_{M}$, as described above. If $\lambda \geq \omega$, then the following conditions are equivalent:

(1) $T^{*}$ is $J-\lambda$-stable, where $T^{*}$ is the center of $T$.

(2) $T_{A}^{C}$ is $\lambda$-stable.

Theorem 2. Then the following conditions are equivalent:

(1) $T_{M}^{*}-\omega$-categorical;

(2) $T_{A}^{C}-\omega$-categorical.

\section{References}

1 Yeshkeyev A.R. Jonsson sets and some of their model-theoretic properties. Abstracts Book. International Congress of Mathematicians. - August, 13-21, 2014. - Seoul, Korea. - P. 8.

2 Yeshkeyev A.R. On Jonsson sets and some their properties // Bulletin of Symbolic Logic. - 2015. Vol. 21. No. 1. - P. 99, 100.

3 Yeshkeyev A.R. Properties of central type for fragments of Jonsson sets // Bulletin of Symbolic Logic. 2016. - Vol. 22. - No. 3. - P. 429, 430. 
4 Ешкеев А.Р. Йонсоновские теории и их классы моделей / А.Р. Ешкеев, М.Т. Касыметова. - Караганда: Изд-во КарГУ, 2016. - С. 346.

5 Мустафин Т.Г. Введение в прикладную теорию моделей / Т.Г. Мустафин, Т.А. Нурмагамбетов. Караганда: Изд-во КарГУ, 1987. - С. 39-51.

6 Yeshkeyev A.R. Some properties of Morly rank over Jonsson sets // Bulletin of the Karaganda University. Ser. Mathematics. - 2016. - No. 4(84). - P. 57-62.

\title{
A.P. Ешкеев
}

\section{EPSCJ теориялардың централды-орбиталды түрлерінің қасиеттері}

\begin{abstract}
Мақала өз мағынасы бойынша йонсондық теориялардың модельді-теоретикалық қасиеттерінің сұрақтары зерттелген. Сонымен қатар осы оқытудың жаңа әдісі ұсынылды. Жаңа ұғым ретінде централдыорбиталды типтің идеясы қолданылды. Йонсондық теорияларды оқу барысында келесі фактілер пайданылды: синтаксистік, йонсондық теорияға қатысты және қарастырып отырған йонсондық теорияның йонсондық ішкі жиындардың семантикалық моделі. Сонымен қатар берілген йонсондық жиындармен байланысты сигнатураның байытылуы синтаксистік мағынада негізгі роль атқарады. Қарастырып отырған сұрақтардың семантикалық тұрғы, ең алдымен, дөңестілік, қатты дөңестілік және экзистенционалды жайлылық ұғымдарымен байланысты. Бұл анықтамалар теориямен байланысты болғандықтан, факт бойынша біз экзистенционалды-тұйық болатын модельдердің әр түрлі түрлерімен жұмыс жасауға тура келеді.
\end{abstract}

Kiлm сөздер: йонсондық теория, йонсондық жиын, йонсондық жиынның фрагменттері, экзистенциалды жай қатты дөңес йонсондық теория, централды-орбиталды типтер.

\section{A.P. Ешкеев}

\section{Свойства центрально-орбитальных типов EPSCJ теорий}

Статья по своему содержанию относится к вопросам изучения теоретико-модельных свойств йонсоновских теорий. При этом предложен новый подход такого изучения. В качестве нового понятия использована идея центрально-орбитального типа. При изучении йонсоновских теорий учтены следующие факты: синтаксический, касающийся йонсоновских теорий и йонсоновских подмножеств семантической модели, рассматриваемой йонсоновской теории. Кроме этого, особую роль в синтаксическом смысле играет обогащения сигнатуры, связанные с заданными йонсоновскими множествами. Семантический аспект рассматриваемых вопросов, в первую очередь, связан с понятием выпуклости, сильной выпуклости и экзистенциальной простоты. Хотя эти определения связаны с теорией, по факту мы имеем дело с различными видами моделей, которые являются экзистенциально-замкнутыми.

Ключевые слова: йонсоновская теория, йонсоновское множество, фрагменты йонсоновских множества, экзистенциальная простая сильно выпуклая йонсоновская теория, центрально-орбитальные типы.

\section{References}

1 Yeshkeyev, A.R. (2014). Jonsson sets and some of their model-theoretic properties: abstracts Book. International Congress of Mathematicians, 13-21, August, Seoul, Korea.

2 Yeshkeyev, A.R. (2015). On Jonsson sets and some their properties. Vestnik simvolicheskoi lohiki Bulletin of Symbolic Logic, Vol. 21, 1, 99, 100. 
3 Yeshkeyev, A.R. (2016). Properties of central type for fragments of Jonsson sets. Vestnik simvolicheskoi lohiki - Bulletin of Symbolic Logic, Vol. 22, 3, 429, 430.

4 Yeshkeyev, A.R., Kasymetova, M.T. (2016). Ionsonovskie teorii i ikh klassy modelei [Jonsson theory and its classes of models]. Karaganda: Izdatelstvo KarHU [in Russian].

5 Mustafin, T.G., Nurmagambetov, T.A. (1987). Vvedenie $v$ prikladnuiu teoriiu modelei [Introduction to applied theory of models]. Karaganda: Izdatelstvo KarHU [in Russian].

6 Yeshkeyev, A.R. (2016). Some properties of Morly rank over Jonsson sets. Vestnik Karagandinskogo universiteta. Ser. Matematika - Bulletin of the Karahanda University. Ser. Mathematics, 4(84), 57-62. 